\title{
Black-Boxing Sustainability
}

\author{
Louis Rice (Corresponding author) \\ University of the West of England, Bristol, England \\ Tel: 44-117-328-3058Ｅ-mail: louis.rice@uwe.ac.uk
}

Received: June 1, 2011

Accepted: June 27, 2011

doi:10.5539/jsd.v4n4p32

\begin{abstract}
The term 'sustainable' has rapidly become a ubiquitous prefix for many contemporary issues, professions and disciplines. This paper contextualizes the debate by exploring how the term 'sustainable' has emerged within the field ofarchitecture. The paper examines the semiotics of sustainability; how the meaning of this word has been produced from an assemblage of words, signs and practices. Adopting'Actor-Network Theory' (ANT) methodology to examinethe embedding of sustainabilityasthe dominant paradigm in architecture. The creation of a definition of sustainability has been hybridized into a social, legal, economic, political and scientific framework. A process of 'sustainabilization' has occurred not only within architecture but across a number of different subjects. The research investigates how carbon-dioxide has played an important role in the promulgation of sustainability. The current framework within which 'sustainability' operates is currently too narrow and inflexible (i.e. black-boxed) with too much emphasis on $\mathrm{CO} 2$ to respond meaningfully to the demands from human development.
\end{abstract}

Keywords: Sustainability, Actor-Network Theory, Architecture, Urban Design, Hybrid, Knowledge, Power

\section{Sustainability hybrids}

Sustainability is often defined as "development which meets present needs without compromising the ability of future generations to achieve their needs and aspirations" (Brundtland, 1987). This definition, commissioned by the United Nations (UN), has been incredibly influential in steering governments, politicians, economists, sociologists and scientists into action to protect the environment in the name of sustainability. The UN's relatively loose description of sustainability has subsequently been pinned down to more specific concerns; into a hybrid assemblage comprising such heterogenous elements as "ecology, wildlife, natural resources, social conditions, behaviour and economic well-being" (Williams et al, 2000:3). Sustainability has become a complex imbroglio of science, technology, sociology, economics, politics and nature. Understanding sustainability cannot involve separating out knowledge, power, science or nature; as they are all tied together into a collective concept. 'Sustainability'is explored here in its broadestsense, but this paper examines the subject synecdochically, situating it in an examination of how architecture became 'sustainabilized'.

\subsection{Sustainable architecture}

'Sustainable architecture' in the 1960's and 1970' was the preserve of a few maverick urbanists and eccentric ecological architects. The most notablearchitects of the era was Buckminster Fuller who explored such notions of sustainability through his ecological megastructures and books such as 'Operating Manual for Spaceship Earth' (1969) and 'Approaching the Benign Environment'(1970). Early pioneers of sustainability, such as Fuller lead to the founding of groups such as the think-tank 'The Club of Rome' who carried out one of the first comprehensive studies of sustainable development. Their 1972 book 'The Limits to Growth' set out to "reconcile sustainable progress within environmental constraints" (Meadows et al, 1972). Even after the 1970's energy crises, this strand of sustainability was relatively peripheral tomainstream architecture that devoted much of the 1980 's and 1990's dealing with aesthetic issues such as postmodernism, decoration and deconstruction. Nonetheless sustainability in architecture and the built environment was to have its resurgence at the turn of the millennium. In the UK, the Government created the Urban Task Force that produced an influential report (1999) promoting sustainable architecture and sustainable cities. A UKGovernmental White Paper (Department for Environment, Transport and the Regions, 2000) supported the Urban Task Force'sambitions andtheir work formed the basis for the UK government's insistence on 'sustainable development' through its main directive 'Planning Policy Statement 1: Delivering Sustainable Development' (Office of the Deputy Prime Minister, 2005) which made mandatory the 'delivery of sustainable development through the planning system'. The Royal Institute of British Architects and the Royal Town Planning Institute followed with requirements and guidance on the promotion of sustainable architecture, urban design and planning. A similar pattern of events occurred across Europe and beyond to embed Brundtland's ambition into a legal, social, political, economic and environmental framework. The European Union included 'sustainable development' as its fundamental objective in EU 'The Treaty of Amsterdam' in 1997, and further strengthened its position with the publication of the first EU sustainable development strategy in 2001 (Commission of the European Communities).

Sustainable architecture had arrived at last, but there was one minor problem, the question remained 'What is sustainable architecture?' 


\section{Actor-Network Theory}

Actor-Network Theory (ANT) has been adopted as a methodology to unpick how the question 'What is sustainable architecture?' was answered.ANT has been used for the last three decades for exploring how hybrid concepts, facts and knowledge have been constructed. ANT argues that scientific facts are constructed to fit within the dominant paradigmand that the certainty of facts and knowledge is more ambiguous during the construction phase of a problem (Latour and Woolgar, 1979; Latour, 1987; Latour, 2005). Actor-Network Theory (ANT) follows the relationships and networks between actors where "entities take their form and acquire their attributes as a result of their relations with other entities" (Law \& Hassard, 1999:3). ANT describes how almost any object or thing is an actor (more accurately an 'actant') in this network, for example treatinghuman behaviour in the same manner as animals (Callon, 1986) machines (Latour, 1992; Latour, 2007)or inanimate objects (Akrich, 1992).ANT uses this hybrid approach by treating all actors the same or (as ANT describe it) 'symmetrically' (Law, 2004). In the unpicking of the question 'What is sustainable architecture?' there is to be found a complicated mesh of natural, technical and social worlds that need to be dis-assembled (Latour, 1993). The next sections uses ANT methods to frame the investigation.

\subsection{Obligatory Passage Point}

The concept of an 'obligatory passage point'describes how a system is constructed to require a mandatory action (Callon, 1986). 'Obligatory passage point' is predicated on controlling all of the actors and variables in order to make them perform a predetermined course of action, i.e. to pass through this one point. According to both UK Building Regulations and Planning Laws all buildings must now be 'sustainable'; thus sustainability has now become an 'obligatory passage point' for architecture (HM Government, 2010). This obligatory passage point, in practice, is a series of measurements and performance indicators that serve as a proxy for 'sustainability'. The adoption of this obligatory passage point has been so extensivethat it is already an accepted proof of sustainable architecture, i.e. it has been 'black-boxed'.

\subsection{Black-Boxes}

"The word black box is used by cyberneticians whenever a piece of machinery or a set of commands is too complex. In its place they draw a little box about which they need to know nothing but its input and output." Latour(1987:2-3)

The term 'black-box' in thesocial sciences describes accepted and agreed pieces of knowledge. A black-box is often part of a more complicated system that is so unquestioned and stable that it can be ignored within that system. Latour (1999:304) describes the making of a black-box as "the way scientific and technical work is made invisible by its own success...Thus, paradoxically, the more science and technology succeed, the more opaque and obscure they become. "Black-boxes are rarely opened or questioned; it is time consuming and often expensive to do so (Latour, 1987). Nonetheless a black-boxoccasionally does gets opened; for example, if a building collapses then the 'black-box' of the structural engineer's calculations would be opened for investigation and critique. The stability and certainty of the black-box collapses along with the building,resulting in more uncertain and contingent knowledge. Fortunately buildings rarely collapse, and rarer still that the black boxes of structural engineers need to be opened.

It is difficult to open a black-box as complex as 'sustainability'; as within this black-box are many more black-boxes, each one a closed, fixed, stable world (Latour, 1988).Let us open the smaller black-box of 'sustainable architecture'. The definition of 'what is sustainable architecture' has been dominated by the black-box: 'Building Energy Rating' (BER) which is part of the European Union's directive on the energy performance of buildings (Commission of the European Communities 2008). BER is an energy rating for a building based on the energy ratings used for household electrical appliances such as fridges or cookers, and uses a scale from ' $A$ ' indicating the most energy efficient building to ' $G$ ' being the least. BER itself is a black box made up of an assemblage of different indicators (i.e. more black-boxes) of sustainability, including the energy use for: water heating, ventilation, space heating and lighting.

In this process of constructing the current BER black-box, many other alternative or possible black-boxes have been discarded, destroyed or ignored; specifically social and economic issues. Sustainabilized architecture operates on the micro-scale; the current indicators used by the BER are very narrow andfocused almost solely on $\mathrm{CO} 2$ reduction. Macro-level questions and investigations such as whether new architecture is required at all, or how it impacts on larger issues such as globalization or international migration are, at present, excluded from definitions of 'sustainable architecture'. Macro-level questions such as these are so far from being black-boxed, many do not even exist as clear questions; yet some of these themes need to be brought into the debate. The approach that towards a political and/or convenient definition of sustainability is in conflict with the very real requirement for architecture that responds to the multiplicity of conditions inherent in Brundtland's definition of sustainability: an equitable distribution of society, economics and the environment.

Each of the BER indicators are just one of a myriad of possible indicators of sustainability; but through some process of selection, (explored in more detail later) it is these indicators that have been constructed to represent the sustainability of the building. BER is not based on the actual consumption of energy of the building, but on 
predicted levels of energy-use based on computer modelling of the buildings materials, construction, expectations of habitation, location, climate etc. BER represents sustainability: whether or not it is a good or bad representation is not of concern here; what is significant is what BER represents. BER is already a black-box of sustainability; a closed system of complex relationships and measurements that represents sustainability as fact. The letter 'A', 'B' or ' $G$ ' are representations of a hybrid world of research, measurement, controversies, politics, economics, power, authority, technology etc that have been displaced and replaced with a single letter, literally stuck onto the entrance of each new building.

Sustainable architecture is a complex hybrid of social, political, technical and social worlds, yet it has been 'black-boxed' within a very short space of time; it has taken less than a decade for all of the uncertainties to be removed and replaced with accepted bits of knowledge;'What is sustainable architecture?' has already been definitively answered. A decade ago there was little agreement on what a sustainable building would or should be; however only a few years later a building can be measured, assessed, controlled and recorded in order to prove that it is 'sustainable'. In order to understand how this has happened, the 'black-box of sustainability' must be opened and its contents explored.

ANTexplains thatthe production ofa black-box is through a process called'translation' (Star, 1991). Translation "permits an explanation of how a few obtain the right to express and to represent the many silent actors of the social and natural worlds they have mobilized" (Callon, 1986:215). This translation is broken down into four stages:problematisation, interessement, enrolment and finally mobilisation. The paper investigates each of these stages in turn to follow the making of a sustainable black-box.

\subsection{Problematisation}

Problematisation is how the discourses on sustainability were established into a rigid context and frame of reference. Callon (1986:202) describes problematisation as "how to become indispensable". Sustainable architecture was a peripheral concern for much of the 20th century, yet has emerged as "the' central issue of the $21 \mathrm{st}$; this has been achieved through the problematisation of sustainability. Moreover 'sustainability' has been so successfully problematised it now forms an obligatory passage point for all new architecture.

The problematisation of sustainability has involved a broad range of different 'actants' into a hybrid network. In order to 'be' sustainable, a building involves parts of the social, physical and natural worlds. 'What is sustainable architecture?' is a simple enough question, but resolving it involves complex and fluxive "imbroglios of science, politics, economy law, religion, technology, fiction"(Latour, 1993: 3) It must combine the actions of entities such as: the vagaries of human users, microbes constituting air quality, the properties of gaseous mixtures passing through the windows, laws of physics concerning the thermodynamics of heat, the $\mathrm{CO} 2$ footprint of the building materials etc. All of these actants have been assembled together as part of the problematisation of sustainability. To understand this problematisation we need to resolve who are the actants by "establishing their identities and the links between them" (Callon, 1986:202).

Sustainability became a key concern for architects because of the emergence of the meta-narrative of climate change, particularly the role of Carbon Dioxide.This once relatively harmless and natural chemical compound was transformed through discourse into an unnatural and harmful pollutant. As buildings and the built environment play a significant part towards carbon footprints (United States Environmental Protection Agency, 2010)then relating CO2 to sustainability and architecture was the principal problematisation in early 2000 . The sustainability discourse problematised architecture into its frame of reference, rather than architecture problematising sustainability. How did sustainability do this? Through a network of scientists, politicians, architects etc arguing for a standardized and mandatory approach; and they did so through 'interessement'.

\subsection{Interessement}

"To interest other actors is to build devices which can be placed between them and all other entities who want to define their identities otherwise. A interests B by cutting or weakening all the links between $B$ and... C, D, E’” Callon (1986:205)

Sustainability interests other actants by building links between them and cutting ties to other actants. For example, sustainability established links with architecture; the role of $\mathrm{CO} 2$ became the principal concern for buildings. Sustainability interessed all aspects of a building:the water usage in cisterns, the CO2 footprint used during construction, whetherhumans close curtains correctly, to the automatic dimming controls for lighting etc. In interessing in this way, existing links with other concerns were cut or minimized. Diminished are the links between architecture and other issues. For much of the preceding decades, the principal concerns of architecture were issues such as: post-modernism, deconstruction or decoration; yet there is now exiguous debate on these concerns. Mostof these earlier relationships have been replaced by the sustainability discourse.

\subsection{Enrolment}

Once interessement has occurred, there is still no guarantee that these form rigidly connected relationships, i.e. enrolment (Star, 1991). The aim therefore is to transform the question 'What is sustainable architecture?' into a statement such as 'Sustainable architecture is' (for example) BER rating 'A'. Enrolment thus "designates the 
device by which a set of interrelated roles is defined and attributed to actors who accept them" (Callon, 1986: 206). For sustainability to succeed in its enrolment of architecture for example; then architects, the RIBA and schools of Architecture must be willing to agree to their role. Furthermore, along with Architecture, other professions were enrolled, such as the Royal Town Planning Institute and Institute of Civil Engineers.Sustainability enrolled even more allies; for example, Part L of the Building Regulations (2010) which deals with the conservation of energy, had been unchanged for over a decade until 2002, but since the enrolment of Part L into sustainability, there have been three changes in eight years with a fourth change imminent in 2012. Each change to Building Regulation Part L further enrolls architecture into sustainability.

\subsection{Mobilisation}

"Who speaks in the name of whom? Who represents whom? These crucial questions must be answered if the project... is to succeed. This is because, as with the description of interessement and enrolment, only a few rare individuals are involved." (Callon, $1986: 208)$

Who represents 'sustainability'? Who or what (or where) is the spokesperson for 'sustainability'? The construction of the definition 'sustainable' does not include all possible factors - only a few factors are elected as representatives for sustainability. The principlerepresentation of a 'sustainable' building is how much $\mathrm{CO} 2$ is used.Mobilization of sustainability thus requires getting $\mathrm{CO} 2$ to be its spokesperson.

How do scientists get $\mathrm{CO} 2$ to 'speak'? This is a complicated task because $\mathrm{CO} 2$ has no voice of its own; it can only be spoken for by others, some are willing to act as voice of $\mathrm{CO} 2$ whilst others are made to act (Law, 1999).CO2 speaks in a number of ways: it is measured, counted, observed, weighed, sampled, and all of this is inscribed onto images, datasets, spreadsheets, graphs,pie-charts, Keeling Curves and indexes(Mol, 1999). For example, the kilowatt per hour $(\mathrm{kw} / \mathrm{h})$ reader on a boiler produces pulses of electricity that are converted into data outputs resulting ultimately with inscriptions of $\mathrm{CO} 2$ usage. When $\mathrm{CO} 2$ is measured and counted as part of this process; each individual molecule of CO2 "is equivalent to a vote" (Callon 1986: 209). Each CO2 molecule and each vote becomes the voice for $\mathrm{CO} 2$; and over the last decade $\mathrm{CO} 2$ production is so large now that it is argued that $\mathrm{CO} 2$ not only has a voice but is screaming at us to act (Gore, 2006). CO2 has seemingly voted for 'regime change' through sustainable: architecture (and transport, politics, health, food, shopping etc) (Stern, 2006).

$\mathrm{CO} 2$ initially acted as a spokesperson for sustainability, like a union representative on behalf of its members. Mobilization has gone further; $\mathrm{CO} 2$ not only speaks for others, it causes others to act on its behalf. Those called into action by $\mathrm{CO} 2$ are a hybrid network of the physical, social and semiological (Farias, 2010). Each of their votes are counted as more allies who are interessed, enrolled and mobilized. Human users are enrolled into the performing of sustainability (Law, 1999) for example, as the temperature on the boiler is turned down a degree, jumpers are put on; architecture merges with the human-user and some of the U-value(a measure of how much heat is lost) of the building is now inscribed via the jumper onto the body of each user. Similarly each user is nudged into reducing $\mathrm{CO} 2$ usage, adjacent to each light-switch is a sign saying 'PLEASE SWITCH OFF THE LIGHTS!'; sustainability has combined in this one instance: part-human, part-technology, part-semiotics and part-architecture into a hybrid network (Law, 2009).

However, there is a much higher chance that things will not perform as necessary with such complex hybridization required to interesse, enroll and mobilize sustainability. All actants must operate for sustainability to be achieved; if one is incapable or refuses to be enrolled then sustainability fails (Callon, 1986). For example, if the light switch does not work properly, or the wrong bulb is put in, or the user ignores the sign, or the room feels too dark, then mobilisation has failed (and sustainability too). Similarly if human users refuse to put their jumper on, or forget to bring their jumpers then the boiler thermostat gets turned up and the mobilization of sustainability fails.Despite sustainable development being the central part to the UK's Governments multifarious policies, their own indicators (i.e. black-boxes) of sustainability show a failure to reduce $\mathrm{CO} 2$ emissions over the last decade.

\section{Closing the Black-Box}

This paper has explored the wider discourse on sustainability through its application in architecture. We have followed how 'sustainable architecture' has beenconstructed in a number of ways. First of all the broader concerns of sustainability have been successfully problematised such that architecture must pass through theobligatory passage pointof 'sustainability'. Secondly, sustainability assembled links to many parts of architecture by interessement. 'Sustainability' became the new building block for constructing architecture. The next step towards a black-box was to solidify the links made during interessement;i.e. allies needed to be enrolled. Architecturewas enrolled into the sustainability meta-narrative; all University architecture courses, practicing architects, related professions, Planning and Construction Laws were enrolled into a network that now operates as a standardized framework. Lastly sustainability mobilized it most vocal and powerful ally - Carbon Dioxide. CO2 spoke on behalf of sustainability; through various inscriptions, devices and calculations; each molecule acting as a vote for sustainability. $\mathrm{CO} 2$ measurement lead to the promulgation of sustainability as voting does for democracy. In doing so sustainability has been hybridized into political, social, legal, scientific, 
technological, human and non-human worlds. The question 'What is sustainable architecture?'has been answered through a stabilized and restricted set of indicators (i.e. black-boxes) related to energy efficiency. This focus on limited aspects of environmental sustainability has been at the exclusion of wider ecological, equitable, social and economic concerns.Ten years on, sustainability has been black-boxed, all the debates over what makes a building sustainable are deemed resolved, fixed, accepted and certain. Without holistic, open and flexible approaches to sustainability that respond to the very real pressures the world is facing, then the important role that architecture could play will lie unrealized. The current approach may not only be failing to meet the needs of sustainable development, but could result in a worsening of the situation.

\section{References}

Akrich, M. (1992). The de-scription of technical objects. In: Bijker, W. and Law, J. (Eds.), ed. Shaping Technology, Building Society: Studies in Sociotechnical Change. Cambridge, Mass,: MIT Press, pp 205-225.

Brundtland, G. (ed). (1987). Our Common Future: The World Commission on Environment and Development. Oxford: Oxford University Press.

Buckminster Fuller, R. (1969).Operating Manual for Spaceship Earth. Carbondale: Southern Illinois University Press.

Buckminster Fuller, R. (1970). Approaching the Benign Environment'. Alabama,Alabama Press.

Callon, M. (1986). Some Elements of a Sociology of Translation: Domestication of the Scallops and the Fishermen of St. Brieuc Bay. In: J. Law, ed. Power, Action and Belief: A New Sociology of Knowledge?London: Routledge, pp 196-233.

Commission of the European Communities. (2008). Proposal for a Directive on the Energy Performance of Buildings. Brussels: The commission of the European Communities.

Commission of the European Communities. (2001). A Sustainable Europe for a better world: A European Strategy for Sustainable Development". Brussels: The commission of the European Communities.

Department of the Environment, Transport and the Regions. (2000). Our Towns and Cities: The Future Delivering the Urban Renaissance. London: DETR.

European Union. (1997). Treaty of Amsterdam. London: Stationery Office

Farias, I. (2010). Introduction: decentring the object of urban studies. In:Farias, I. and Bender, T. eds. Urban Assemblages, How Actor-Network Theory changes urban studies. London: Routledge, pp 1-24.

Gore, A. (2006). An inconvenient truth: The planetary emergency of global warming and what we can do about it. New York: Rodale Books.

HM Government. (2010). The Building Regulations - Part L Conservation of Fuel and Power. London: RIBA.

Latour, B. (1993). We have never been modern. Cambridge, MA: Harvard Univ. Pr.

Latour, B. (1987). Science in action. Cambridge, Mass.: Harvard Univ. Press.

Latour, B. (1988). The pasteurization of France. Cambridge, Mass,: Harvard Univ Press.

Latour, B. (1992). Where are the missing masses? The sociology of a few mundane artefacts. In: Bijker, W. and Law, J. (Eds.), ed. Shaping Technology, Building Society: Studies in Sociotechnical Change. Cambridge, Mass,: MIT Press, pp 225-258.

Latour, B. (1999). Pandora's hope: essays on the reality of science studies. Cambridge, MA: Harvard University Press.

Latour, B. (2005). Reassembling the social: An introduction to actor-network-theory. Oxford: Oxford University Press.

Latour, B. (2007). A textbook case revisited: knowledge as mode of existence . In: E. Hackett, O. Amsterdamska, M. Lynch and J. Wacjman, eds. The Handbook of Science and Technology Studies3rd edition ed. Cambridge: MIT Press, pp 196-229.

Latour, B. and Woolgar, S. (1979). Laboratory life: The construction of scientific facts. Princeton: Princeton Univ $\operatorname{Pr}$.

Law, J. (1999). After ANT: complexity, naming and topology. In: J. Law and J. Hassard, eds. Actor network theory and after. Oxford: Blackwell, pp 1-14.

Law, J. (2004). After method: Mess in social science research. London: Routledge.

Law, J. (2009). Actor-Network Theory and material semiotics. In: Turner, B.S. ed. The new Blackwell companion to social theory. Oxford: Blackwell Publishing, pp141-158.

Law, J. and Hassard, J. eds. (1999). Actor network theory and after. Oxford: Blackwell.

Law, J. ed. (1991). A sociology of monsters. London: Routledge. 
Meadows, D. H.; Meadows, D. L.; Randers, J.;and Behrens W.W. (1972). The Limits to Growth. New York: Universe Books.

Mol, A. (1999). Ontological politics. A word and some questions. In: J. Law and J. Hasard, eds. Actor Network Theory and After. Oxford: Blackwell Publishers/The Sociological Review, pp 74-89.

ODPM (Office of the Deputy Prime Minister). (2005). Planning Policy Statement 1: Delivering Sustainable Development. Office of the Deputy Prime Minister, London.

Star, S. L. (1991). Power, technologies and the phenomenology of conventions: on being allergic to onions. In:Law, J. ed. A sociology of monsters. London: Routledge, pp 26-56.

Stern, Nicholas. (2006). The Stern Review on the Economics of Climate Change. Cambridge: Cambridge University Press.

United States Environmental Protection Agency. (2010). Inventory of U.S. Greenhouse Gas Emissions and Sinks: 1990 - 2008. Washington: United States Environmental Protection Agency.

Urban Task Force. (1999). Towards an Urban Renaissance. London: DETR.

Williams, K., Burton, E. and Jenks, M. (2000). Achieving sustainable urban form: an introduction. London, Spon. 